\title{
The impact of obesity on the cellular and molecular pathophysiology of COVID-19
}

\author{
P Dhanraj, BSc (Hons); R Pitere, MSc; M S Pepper, MB ChB, PhD, MD, PD \\ Department of Immunology, Institute for Cellular and Molecular Medicine, SAMRC Extramural Unit for Stem Cell Research and Therapy, \\ Faculty of Health Sciences, University of Pretoria, South Africa
}

Corresponding author: M S Pepper (michael.pepper@up.ac.za)

Emerging evidence reveals a strong association between COVID-19 and obesity in terms of disease severity, need for hospitalisation and risk of mortality. In this review, we discuss cellular and molecular mechanisms potentially contributing to the pathophysiology of COVID-19 in obese patients. Understanding the relationship between COVID-19 and obesity is pertinent for the clinical management of these patients.

S Afr Med J 2021;111(3):211-214. https://doi.org/10.7196/SAMJ.2021.v111i3.15398

In December 2019, the World Health Organization (WHO) was informed of an increasing number of pneumonia cases observed in Wuhan City, China. ${ }^{[1]}$ The disease is caused by the pathogen severe acute respiratory syndrome coronavirus 2 (SARS-CoV-2), ${ }^{[2]}$ and has since been termed coronavirus disease 2019 (COVID-19). ${ }^{[1]}$ COVID19 was declared a global pandemic, ${ }^{[1]}$ with $\sim 64$ million cases and more than 1.4 million deaths reported to date. ${ }^{[3]}$

There is currently no vaccine or cure for COVID-19. Current recommendations aim to limit viral spread by using nonpharmacological interventions such as maintaining social distancing, wearing protective face masks, hand washing, sanitisation and where necessary, self-isolation following a positive diagnosis or exposure to a SARS-CoV-2-infected person. Symptomatic patients and those presenting with acute respiratory infections may require supplemental oxygen, corticosteroids (dexamethasone and others) and systemic anticoagulation. Attempts have been made to reduce viral load using oseltamivir, normally used to treat influenza type $\mathrm{A}$ and $\mathrm{B}$, and remdesivir, a repurposed drug developed for Ebola. Treatments aimed at reducing the impact of the cytokine release syndrome (CRS) or cytokine storm include tocilizumab, an anti-IL-6 receptor monoclonal antibody. ${ }^{[4,5]}$ Clinical trials are underway to determine the effects of convalescent plasma from patients with high titres of SARS-CoV-2, administered within 72 hours of diagnosis, ${ }^{[4]}$ and the data to date are equivocal.

Disease severity is greater in some patients than in others. Most COVID-19 patients are asymptomatic or exhibit mild to moderate disease. A minority exhibit severe complications including acute respiratory distress syndrome and multiple organ failure, requiring hospitalisation with supplemental oxygen and assisted ventilation. ${ }^{[6-8]}$ Older people, men and those with underlying conditions are at higher risk of severe illness. Risk factors for severe illness and death include hypertension, cardiovascular disease, diabetes, chronic kidney disease, chronic obstructive pulmonary disease (COPD), cancer and obesity. ${ }^{[9-12]}$

\section{Selection criteria}

Relevant literature was retrieved from PubMed and Google Scholar using the key words 'COVID-19 and comorbidities', 'obesity and COVID-19', 'obesity and ACE2', 'obesity and immune response' and 'obesity and cellular and molecular mechanisms'. From these sources, we evaluated and selected articles on the epidemiology, and cellular and molecular mechanisms of COVID-19 in the context of obesity. This is not an exhaustive systematic review or a meta-analysis but rather a descriptive review in an ever-changing field of some of the key pathogenetic mechanisms to have emerged in a disease whose existence we have known about for less than a year.

\section{Obesity and COVID-19}

Obesity is a global pandemic and has almost tripled in prevalence since the 1970s. The WHO defines obesity as the accumulation of fat, which can negatively affect health. Overweight people have a body mass index (BMI) $>25$ and a BMI $\geq 30$ is defined as obesity. Obesity affected more than 650 million people globally in 2016 and is a risk factor for cardiovascular disease, type 2 diabetes mellitus, kidney disease and cancer. An increase in BMI and adiposity also increases the risk of contracting infections. ${ }^{[14]}$ Developed countries have a higher prevalence of obesity, but urbanisation and globalisation have led to a surge of obesity in developing countries. ${ }^{[15]}$

COVID-19 patients with obesity, and mostly males, present with severe disease. They often require hospitalisation and mechanical ventilation, are admitted to the intensive care unit (ICU) and have a higher probability of mortality. ${ }^{[9,16-21]}$ Data from Africa are lacking, but global trends suggest that obesity is also a risk factor for more severe COVID-19 disease in African populations.

The strong association between COVID-19 and obesity is not well understood. In this article, we review the potential cellular and molecular mechanisms contributing to severe COVID-19 in obese patients.

\section{The pathophysiology of obesity and COVID-19}

Immunopathogenesis

Obesity in the general population is associated with a depressed immune system and chronic low-grade inflammation characterised by an increase in adipokines and pro-inflammatory cytokines. ${ }^{[22]}$ When obese patients are infected with COVID-19, the two pathologies appear to act in concert to further impair immune function and elicit a more severe inflammatory response, resulting in more severe COVID-19 disease. ${ }^{[21,23,24]}$ The CRS, an uncontrolled and excessive production of pro-inflammatory cytokines has been observed in critically ill COVID-19 patients. ${ }^{[25-27]}$ Various cytokines are released, including interleukin-1 (IL-1), IL-6 and IL-10, as well as 
growth factors, colony-stimulating factors, interferons, macrophage inflammatory proteins and tumour necrosis factor alpha (TNFa). Most studies have found significantly increased levels of IL- 6 and TNFa in COVID-19 patients. ${ }^{[25,26]}$ These pro-inflammatory cytokines increase vascular permeability, which causes blood cells and fluid to enter alveoli, producing symptoms such as dyspnoea ${ }^{[28]}$ The CRS is believed to be responsible for the presentation of acute respiratory distress syndrome (ARDS) and multi-organ failure in some COVID19 patients. ${ }^{[25,26]}$

To respond effectively against viral infections, our immune systems rely on optimally functioning $\mathrm{T}$ cells. Low $\mathrm{T}$ cell counts are a known risk factor and predictor of poor prognosis and mortality in COVID19 patients. ${ }^{[29,30]}$ In Wuhan, China, patients with severe COVID-19 had significantly fewer cytotoxic and helper T cells. ${ }^{[30]}$ Defective $\mathrm{T}$ cell-mediated immune responses have also been observed in obese patients, who are more likely to be hospitalised if they acquire respiratory infections. ${ }^{[31]}$

Immune dysregulation in obese people may also include reduced antiviral cytokines, diminished natural killer cell activity and dysfunctional macrophages. ${ }^{[32-34]}$ Impaired activation and functioning of $\mathrm{CD} 4^{+}$and $\mathrm{CD} 8^{+} \mathrm{T}$ cells have been observed in overweight and obese individuals who were infected with the H1N1 virus, which may have contributed to disease severity and mortality. ${ }^{[35]}$ When infected with influenza A/Puerto Rico/8/34 (A/PR8), obese mice showed reduced expression of interferon alpha (INF $\alpha$ ) and INF $\beta$ in the early stages of infection and this remained low throughout the infection. ${ }^{[32]}$ These mice had diminished natural killer cell proliferation and activity in the lungs. ${ }^{[32]}$ Other forms of immune dysregulation observed in obese mice infected with influenza included reduced expression of monocyte chemoattractant protein 1 (MCP-1), regulated upon activation normal $\mathrm{T}$ cell expressed and secreted (RANTES) and a delayed expression of the essential cytokines, TNF $\alpha$ and IL6. ${ }^{[32]}$ Obese people who had severe H1N1 disease had reduced macrophage activation and cytotoxic activity. ${ }^{[33]}$ It is possible that the dysfunction in the innate immune system of obese patients may also contribute to the severity of COVID-19 symptoms.

Another link between the severity of COVID-19 disease and obesity may be the chronic production of leptin due to an increased number of adipocytes. ${ }^{[36,37]}$ The immune response becomes dysregulated when T cells and natural killer cells become resistant to leptin. ${ }^{[38]}$ High levels of leptin were associated with disease severity and mortality in obese mice infected with H1N1. ${ }^{[39]}$ Leptin also increases the production of leukotrienes by alveolar macrophages and may ultimately cause pulmonary inflammation. ${ }^{[40]}$

\section{Adipose tissue, obesity and receptors for SARS-CoV-2}

Adipose tissue expresses receptors such as angiotensin-converting enzyme-2 (ACE2) and dipeptidyl peptidase 4 (DPP4), which facilitate the entry of SARS-CoV-2 into human cells and increase viral load. ${ }^{[41]}$

In the lungs, SARS-CoV-2 binds to the ACE2 receptor, upregulating the expression of ACE2 and damaging alveolar cells. ${ }^{[42]}$ The ACE2 receptor is overexpressed in the adipose tissue of COVID-19 patients. ${ }^{[43,44]}$ Since obese people have more adipose tissue, they are expected to have more ACE2 receptors. ACE2 receptors are expressed in monocytes and macrophages, ${ }^{[45]}$ which are also more prevalent in the adipose tissue of obese people. ${ }^{[46,47]}$ It is therefore likely that adipose tissue acts as a viral reservoir and possibly allows for inter-organ transmission. ${ }^{[43,44]}$ When cells bearing ACE2 receptors are infected, their immunomodulatory activity is impaired and they produce proinflammatory factors which contribute to inflammation. ${ }^{[48]}$ Monocytes expressing ACE2 are involved in regulating blood vessel homeostasis through the renin-angiotensin-aldosterone system (RAAS). When SARS-CoV-2 activates ACE2 on monocytes, this disturbs the RAAS, resulting in acute coronary syndrome. ${ }^{[49]}$

SARS-CoV-2 may also enter cells of the respiratory tract via DPP4, a receptor used by the middle east respiratory syndrome coronavirus (MERS-CoV) ${ }^{[50]}$ and also known as cluster of differentiation 26 (CD26). ${ }^{[51,52]}$ DPP4 is a membrane-bound glycoprotein with multiple functions including glucose and insulin metabolism and immune regulation. ${ }^{[53]}$ DPP4 was identified as a potential SARS-CoV-2 receptor using bioinformatic and protein-docking prediction tools. ${ }^{[50]}$ In obese people, DPP4 is overexpressed in visceral adipose tissue and the liver. ${ }^{[5,55]}$ DPP4 has immunomodulatory activity, activating and causing the proliferation of $\mathrm{T}$ cells and production of cytokines, and potentially contributing to and exacerbating hyperinflammation. ${ }^{[4-56]}$

\section{Obesity-associated comorbidities and SARS-CoV-2}

Obesity is associated with various comorbidities that may contribute to the severity of COVID-19. Obese people are disproportionately affected by hypertension, type 2 diabetes, pulmonary diseases and cancer, ${ }^{[57,58]}$ which have also been identified as risk factors for severe COVID-19. ${ }^{[59]}$

Obesity affects the functioning of the respiratory system and is associated with several respiratory conditions including sleep apnoea, asthma, obesity hypoventilation syndrome, COPD, pulmonary hypertension, aspiration pneumonia, pulmonary embolism (PE),$^{[1,60,61]}$ and respiratory infection. ${ }^{[31]}$ Obese people are more likely to accumulate adipose tissue around the upper airways, chest wall and abdomen, impairing the mechanics of the lungs. ${ }^{[62]}$ Obesity is also a risk factor for venous thromboembolic diseases, which include deep vein thrombosis and PE. Recent comparisons suggest that overweight or obese COVID-19 patients are more prone to developing $\mathrm{PE}$, possibly due to the presence of excess adipose tissue. ${ }^{[63,64]}$ The risk of thrombosis increases with increasing BMI and waist circumference. Thromboembolic disease is caused by chronic inflammation, adipokines, an increase in coagulation activity, a decrease in fibrinolytic activity and procoagulant microparticles. ${ }^{[65]}$

Obesity is also associated with the development and progression of chronic kidney disease and end-stage renal disease. ${ }^{[66]}$ Preexisting or underlying kidney disease were identified as risk factors for severe COVID-19 (83.93\%) and related mortality (53.33\%) in a recent meta-analysis. ${ }^{[67]}$

\section{Obesity and COVID-19 in South Africa}

The prevalence of obesity in South Africa (SA) is increasing rapidly, with at least $68 \%$ of women and $31 \%$ of men reported as being either overweight or obese in 2016. ${ }^{[68]}$ In addition, $13.5 \%$ of school-going children between the ages of 6 and 14 years were reported to be overweight or obese, which is above the $10 \%$ global prevalence. ${ }^{[69]}$ In a country with high rates of unemployment, poverty and infectious diseases such as HIV and tuberculosis, obesity and its associated comorbidities have a negative impact on the livelihoods of many people. The disease burden leads to an increase in healthcare costs at both the individual level and that of the healthcare system. ${ }^{[70]}$

Obesity in SA is driven by high levels of poverty, unemployment and low income. ${ }^{[71]}$ In the first quarter of 2020, Statistics South Africa (Stats SA) reported that the unemployment rate was $30.1 \%$ and $\sim 40000$ jobs had been shed across various sectors. ${ }^{[72]}$ In addition to this, 35.1 million SA adults live below the upper-bound poverty line of ZAR1 227 per month. ${ }^{[73,74]}$ People from low-income households tend to buy less expensive foods which are gastronomically filling and energy-dense, but rich in starch, fat and sugar. ${ }^{[7]]}$ The surge in obesity 
in developing countries such as SA is associated with urbanisation and globalisation, ${ }^{[15]}$ and the increased intake of high-calorie fast foods and the consumption of sugar-sweetened beverages. ${ }^{[15,71]}$ Insufficient physical activity and a sedentary lifestyle are also complicit in weight gain and obesity. ${ }^{[71]}$

Many countries have implemented strategies that limit physical activity to curb the spread of COVID-19, which may have increased the prevalence of obesity. On the 26 March 2020, SA went into an official lockdown due to the COVID-19 pandemic. Restrictions included staying indoors, working remotely, closing of gyms and limited outdoor exercise. ${ }^{[75]}$ In response, many people changed their eating patterns and switched to a more sedentary lifestyle, which created an obesogenic environment. Recently the lockdown restrictions were eased to stimulate economic activity ${ }^{[75]}$ and places selling fast-food were first to open, with fatty and processed foods becoming easily available to the public. Due to a fear of contracting COVID-19, many SA citizens abandoned or froze their gym memberships and have reduced their levels of physical activity. This could exacerbate the rising prevalence of obesity in SA, further increasing the risk of severe COVID-19.

\section{Implications of obesity in the COVID-19 pandemic}

Obese patients generally respond poorly to vaccinations and antiviral treatments. ${ }^{[7]}$ This is most likely due to poor antibody responses or poor absorption of vaccines due to increased adiposity. ${ }^{[38]}$ With several countries in the process of developing COVID-19 vaccines, there is a concern that vaccines may not be effective in obese individuals.

Obese COVID-19 patients also seem to be more contagious than lean patients, ${ }^{[77,78]}$ possibly due to the fact that obesity influences the viral life cycle and increases virus shedding. Viral load is also likely to be greater because of the subdued or delayed immune response, as was seen in the $\mathrm{H} 1 \mathrm{~N} 1$ pandemic. ${ }^{[79,80]}$ Healthcare professionals should therefore be cognisant of the consequences of isolation procedures and make provision for the likelihood of an increase in an obesogenic environment.

The interplay between obesity and COVID-19 has placed an additional burden on healthcare systems globally. Obese patients have suffered disproportionately from COVID-19, requiring hospitalisation and ICU admission and have needed more resources such as ventilators. ${ }^{[9,16,18]}$ In low-resource settings such as SA and particularly in rural areas, the interplay between COVID-19 and obesity could place a severe strain on the healthcare system. Globally, healthcare systems were overwhelmed by sudden peaks in cases, leaving hospitals ill-prepared in terms of resources. These observations highlight major challenges faced by healthcare systems as a consequence of the ongoing increase in the prevalence of obesity.

\section{Conclusions}

Obesity is an independent risk factor for severity and mortality in COVID-19. Obesity increases the need for hospitalisation and mechanical ventilation. In addition to chronic inflammation, obese individuals have defective innate and adaptive immune responses, which are the most plausible links between obesity and severe COVID-19. Increased expression of ACE2 and DPP4 in adipose tissue may increase viral load and drive disease severity. Curbing viral transmission via lockdown restrictions, social distancing and reduced physical activity may enable behaviour that encourages weight gain. The strong association between COVID-19 and obesity-related comorbidities highlights a need for healthcare systems to promote interventions that address non-communicable diseases, including routine health checks, the importance of nutrition and exercise.

\section{Declaration. None.}

Acknowledgements. We would like to acknowledge Dr Cheryl Tosh (University of Pretoria) for her assistance with editing the manuscript. Author contributions. PD and RP contributed equally to writing, reviewing and editing the manuscript. MSP conceived, reviewed and edited the manuscript. All authors approved the manuscript for publication.

Funding. This work was supported by grants from the South African Medical Research Council Extramural Unit for Stem Cell Research and Therapy, the Institute for Cellular and Molecular Medicine of the University of Pretoria (MSP); the South African National Research Foundation grant no. 116943 (PD) and grant no. 114044 (RP); and University of Pretoria postgraduate bursaries (PD and RP).

Conflicts of interest. None.

1. World Health Organization. Timeline of WHO's response to COVID-19. Geneva: WHO, 2020. https:// www.whoint/news-room/detail/29-06-2020-covidtimeline (accessed 18 July 2020).

2. Gorbalenya AE, Baker SC, Baric RS, et al. Severe acute respiratory syndrome-related coronavirus: The species and its viruses - a statement of the coronavirus study group. bioRxiv 2020 (epub 11 February 2020). https://doi.org/10.1101/2020.02.07.937862

3. World Health Organization. WHO coronavirus disease (COVID-19) dashboard. Geneva: WHO, 2020. https:// covid19.who.int/ (accessed 30 November 2020).

4. National Institute of Health. COVID-19 treatment guidelines. Rockville: NIH, 2020. https://wwwcovid19treatmentguidelinesnihgov/whats-new/ (accessed 24 July 2020).

5. Harapan H, Itoh N, Yufika A, et al. Coronavirus disease 2019 (COVID-19): A literature review. J Infect Harapan H, Itoh N, Yufika A, et al. Coronavirus disease 2019 (COVID-19): A

6. Shang Y, Pan C, Yang X, et al. Management of critically ill patients with COVID-19 in ICU: Statement

6. Shang Y, Pan C, Yang X, et al. Management of critically ill patients with COVID-19 in ICU: Statement
from front-line intensive care experts in Wuhan, China. Ann Intensive Care 2020;10(1):73. https://doi. org/10.1186/s13613-020-00689-1

7. Zhou F, Yu T, Du R, et al. Clinical course and risk factors for mortality of adult inpatients with COVID-19 in Wuhan, China: A retrospective cohort study. Lancet 2020;395(10229):1054-1062. https:// doi.org/10.1016/s0140-6736(20)30566-3

8. Wei YY, Wang RR, Zhang DW, et al. Risk factors for severe COVID-19: Evidence from 167 hospitalised patients in Anhui, China. J Infect 2020;81(1):e89-e92. https://doi.org/10.1016\%2Fj.jinf.2020.04.010

. Cai Q, Chen F, Wang T, et al. Obesity and COVID-19 severity in a designated hospital in Shenzhen China. Diabetes Care 2020;43(7):1392-1398. https://doi.org/10.2337/dc20-0576

10. Emami A, Javanmardi F, Pirbonyeh N, Akbari A. Prevalence of underlying diseases in hospitalised patients with COVID-19: A systematic review and meta-analysis. Arch Acad Emerg Med 2020;8(1):e35-e35.

11. Kluge HHP, Wickramasinghe K, Rippin HL, et al. Prevention and control of non-communicable diseases in the COVID-19 response. Lancet 2020;395(10238):1678-1680. https://doi.org/10.1016/S01406736(20)31067-9

12. Yang J, Zheng Y, Gou X, et al. Prevalence of comorbidities and its effects in patients infected with SARS CoV-2: A systematic review and meta-analysis.1878-3511 (Electronic)) https://doi.org/10.1016/j. ijid.2020.03.017

13. World Health Organization. Obesity. Geneva: WHO, 2020. https://www.who.int/health-topics obesity\#tab=tab_1. (accessed 10 July 2020).

14. Dixon AE, Peters U. The effect of obesity on lung function. Expert Rev Respir Med 2018;12(9):755-767. https://doi.org/10.1080/17476348.2018.1506331

5. Fox A, Feng W, Asal V. What is driving global obesity trends? Globalisation or 'modernisation'? Global Health 2019;15(1):32. https://doi.org/10.1186/s12992-019-0457-y

16. Palaiodimos L, Kokkinidis DG, Li W, et al. Severe obesity is associated with higher in-hospital mortality in a cohort of patients with COVID-19 in the Bronx, New York. medRxiv 2020 (epub 9 May 2020). https://doi.org/10.1101/2020.05.05.20091983

17. Petrilli CM, Jones SA, Yang J, et al. Factors associated with hospitalisation and critical illness among 4 103 patients with COVID-19 disease in New York City. medRxiv 2020 (epub 11 April 2020). https:// 103 patients with COVID-19 disease
doi.org/10.1101/2020.04.08.20057794

18. Simonnet A, Chetboun M, Poissy J, et al. High prevalence of obesity in severe acute respiraSimonnet A, Chetboun $\mathrm{M}$, Poissy J, et al. High prevalence of obesity in severe acute respira-
tory syndrome coronavirus-2 (SARS-CoV-2) requiring invasive mechanical ventilation. Obesity tory syndrome coronavirus-2 (SARS-CoV-2) requiring
2020;28(7):1195-1199. https://doi.org/10.1002/oby.22831

19. Hamer M, Gale CR, Kivimäki M, Batty GD. Overweight, obesity, and risk of hospitalisation for COVID-19: A community-based cohort study of adults in the United Kingdom. Proc Nat Acad Sci USA 2020;117(35):21011-21013. https://doi.org/10.1073/pnas.2011086117

20. Hernández-Garduño E. Obesity is the comorbidity more strongly associated for Covid-19 in Mexico. A case-control study. Obesity Res Clin Pract 2020;14(4):375-379. https://doi.org/10.1016/j.orcp.2020.06.001 1. Busetto L, Bettini S, Fabris R, et al. Obesity and COVID-19: An Italian snapshot. Obesity 2020;28(9):1600-1605. https://doi.org/10.1002\%2Foby.22918

22. Makki K, Froguel P, Wolowczuk I. Adipose tissue in obesity-related inflammation and insulin resistance: Cells, cytokines, and chemokines. ISRN Inflammation. 2013;2013:139239. https://doi. org/10.1155/2013/139239

23. Kim J, Nam JH. Insight into the relationship between obesity-induced low-level chronic inflammation and COVID-19 infection. Int J Obes 2020;44(7):1541-1542. https://doi.org/10.1038\%2Fs41366-020-0602-y

24. Korakas E, Ikonomidis I, Kousathana F, et al. Obesity and COVID-19: Immune and metabolic Korakas E, Ikonomidis I, Kousathana F, et al. Obesity and COVID-19: Immune and metabolic
derangement as a possible link to adverse clinical outcomes. Am J Physiol Endocrinol Metab derangement as a possible link to adverse clinical outcomes. An
2020;319(1):E105-E109. https://doi.org/10.1152/ajpendo.00198.2020

25. Coperchini F, Chiovato L, Croce L, Magri F, Rotondi M. The cytokine storm in COVID-19: An overview of the involvement of the chemokine/chemokine-receptor system. Cytokine Growth Factor Rev 2020;53:25-32. https://doi.org/10.1016/j.cytogfr.2020.05.003

26. Ragab D, Salah Eldin H, Taeimah M, Khattab R, Salem R. The COVID-19 cytokine storm: What we know so far. Front Immunol 2020;11:1446. https://doi.org/10.3389/fimmu.2020.01446

27. Tang Y, Liu J, Zhang D, et al. Cytokine storm in COVID-19: The current evidence and treatment strategies. Front Immunol 2020;11:1708. https://doi.org/10.3389/fimmu.2020.01708

28. Zhang C, Wu Z, Li JW, Zhao H, Wang GQ. Cytokine release syndrome in severe COVID-19: Interleukin-6 receptor antagonist tocilizumab may be the key to reduce mortality. Int J Antimicrob Agents.2020;55(5):105954. https://doi.org/10.1016/j.ijantimicag.2020.105954

29. Rosendahl Huber S, van Beek J, de Jonge J, Luytjes W, van Baarle D. T cell responses to viral infections - opportunities for peptide vaccination. Front Immunol 2014;5:171. https://doi.org/10.3389/ fimmu.2014.00171 
30. Du RH, Liang LR, Yang CQ, et al. Predictors of mortality for patients with COVID 19 pneumonia caused by SARS CoV 2: A prospective cohort study. Eur Respir J 2020;2000524. https://doi nia caused by SARS CoV 2: A
org/10.1183/13993003.00524-2020

31. Kornum JB, Norgaard M, Dethlefsen C, et al. Obesity and risk of subsequent hospitalisation with pneuKornum JB, Norgaard M, Dethlefsen C, et al. Obesity and risk of subsequent hospital

32. Smith AG, Sheridan PA, Harp JB, Beck MA. Diet-induced obese mice have increased mortality and altered immune responses when infected with influenza virus. J Nutr 2007;137(5):1236-1243. https://doi. org/10.1093/jn/137.5.1236

33. Ahn SY, Sohn SH, Lee SY, et al. The effect of lipopolysaccharide-induced obesity and its chronic inflammation on influenza virus-related pathology. Environ Toxicol Pharmacol 2015;40(3):924-930. https://doi org/10.1016/j.etap.2015.09.020

34. Michelet X, Dyck L, Hogan A, et al. Metabolic reprogramming of natural killer cells in obesity limits antitumor responses. Nat Immunol 2018;19(12):1330-1340.

35. Paich HA, Sheridan PA, Handy J, et al. Overweight and obese adult humans have a defective cellular immune response to pandemic H1N1 influenza A virus. Obesity 2013;21(11):2377-2386. https://doi org/10.1038/s41590-018-0251-7

36. Rebello CJ, Kirwan JP, Greenway FL. Obesity, the most common comorbidity in SARS-CoV-2: Is leptin the link? Int J Obesity 2020;44(9):1810-1817. https://doi.org/10.1038/s41366-020-0640-5

37. Frasca D, McElhaney J. Influence of obesity on pneumococcus infection risk in the elderly. Front Endocrinol 2019;10:71. https://doi.org/10.3389/fendo.2019.00071

38. Milner JJ, Beck MA. The impact of obesity on the immune response to infection. Proc Nutr Soc 2012;71(2):298-306. https://doi.org/10.1017/s0029665112000158

39. Zhang AJ, To KK, Li C, et al. Leptin mediates the pathogenesis of severe 2009 pandemic influenza $\mathrm{A}(\mathrm{H} 1 \mathrm{~N} 1)$ infection associated with cytokine dysregulation in mice with diet-induced obesity. Infect Dis 2013;207(8):1270-1280. https://doi.org/10.1093/infdis/jit031

40. Mancuso P, Canetti C, Gottschalk A, Tithof PK, Peters-Golden M. Leptin augments alveolar macrophage leukotriene synthesis by increasing phospholipase activity and enhancing group IVC iPLA2 (cPLA2gamma) protein expression. Am J Physiol Lung Cell Mol Physiol 2004;287(3):L497-L502. https://doi org/10.1152/ajplung.00010.2004

41. Xu X, Chen P, Wang J, et al. Evolution of the novel coronavirus from the ongoing Wuhan outbreak and modeling of its spike protein for risk of human transmission. Sci China Life Sci 2020;63(3):457-460 https://doi.org/10.1007/s11427-020-1637-5

42. Sun P, Lu X, Xu C, Sun W, Pan B. Understanding of COVID-19 based on current evidence. J Med Virology 2020;92(6):548-551. https://doi.org/10.1002/jmv.25722

43. Li MY, Li L, Zhang Y, Wang XS. Expression of the SARS-CoV-2 cell receptor gene ACE2 in a wide variety of human tissues. Infect Dis Poverty 2020;9(1):45. https:// doi.org/10.1186/s40249-020-00662-x

44. Kassir R. Risk of COVID-19 for patients with obesity. Obes Rev 2020;21(6):el3034. https://doi. org/10.1111/obr.13034

45. Trojanowicz B, Ulrich C, Kohler F, et al. Monocytic angiotensin-converting enzyme 2 relates to atherosclerosis in patients with chronic kidney disease. Nephrol Dial Transplant 2017;32(2):287-298. https:// doi.org/10.1093/ndt/fww206

46. Friedrich K, Sommer M, Strobel S, et al. Perturbation of the monocyte compartment in human obesity. 6riedrich K, Sommer M, Strobel S, et al. Perturbation of the monocyte conp
Front Immunol 2019;10:1874. https://doi.org/10.3389/fimmu.2019.01874

47. Daemen S, Schilling JD. The interplay between tissue niche and macrophage cellular metabolism in obeDaemen S, Schilling JD. The interplay between tissue niche and macrophage cello
sity. Front Immunol 2020;10:3133. https://doi.org/10.3389/fimmu.2019.03133

48. Jafarzadeh A, Chauhan P, Saha B, Jafarzadeh S, Nemati M. Contribution of monocytes and macrophage to the local tissue inflammation and cytokine storm in COVID-19: Lessons from SARS and MERS, an potential therapeutic interventions. Life Sci 2020;257:118102. https://doi.org/10.1016/j.lls.2020.118102

9. Gomez Rial J, Rivero-Calle I, Salas A, Martinon-Torres F. Role of monocytes/macrophages in COVID-19 pathogenesis: Implications for therapy. Infect Drug Resist 2020;13:2485-2493. https://doi.org/10.2147 IDR.S258639

50. Li Y, Zhang Z, Yang L, et al. The MERS-CoV receptor DPP4 as a candidate binding target of the SARSCoV-2 spike. iScience 2020;23(6):101160. https://doi.org/10.1016/j.isci.2020.101400

51. Solerte SB, Di Sabatino A, Galli M, Fiorina P. Dipeptidyl peptidase-4 (DPP4) inhibition in COVID-19. Acta Diabetol 2020;57(7):779-783. https://doi.org/10.1007/s00592-020-01539-2

52. Vankadari N, Wilce JA. Emerging Wuhan (COVID-19) coronavirus: Glycan shield and structure prediction of spike glycoprotein and its interaction with human CD26. Emerg Microbes Infect 2020:9(1):601604. https://doi.org/10.1080/22221751.2020.1739565

53. Ghorpade DS, Ozcan L, Zheng Z, et al. Hepatocyte-secreted DPP4 in obesity promotes adipose inflam. Ghorpade DS, Ozcan L, Zheng Z, et al. Hepatocyte-secreted DPP4 in obesity promotes adipose inflis
mation and insulin resistance. Nature 2018;555(7698):673-677. https://doi.org/10.1038/nature26138

54. Zhong J, Rao X, Deiuliis J, et al. A potential role for dendritic cell/macrophage-expressing DPP4 in 4. Zhong J, Rao X, Deiuliis J, et al. A potential role for dendritic cell/macrophage-expressing DPP4 in
obesity-induced visceral inflammation. Diabetes 2013;62(1):149-157. https://doi.org/10.2337/db12-0230

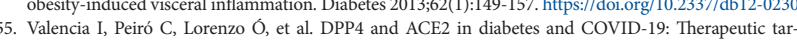
55. Valencia I, Peiró C, Lorenzo O, et al. DPP4 and ACE2 in diabetes and COVID-19: Therapeutic tar-
gets for cardiovascular complications? Front Pharmacol 2020;11:1161. https://dx.doi.org/10.3389/

56. Bassendine MF, Bridge SH, McCaughan GW, Gorrell MD. COVID-19 and comorbidities: A role for dipeptidyl peptidase 4 (DPP4) in disease severity? J Diabetes 2020;12(9):649-658. https://doi. org/10.1111/1753-0407.13052
57. Bray GA. Medical consequences of obesity. J Clin Endocrinol Metab 2004;89(6):2583-2589. https://doi. org/10.1210/jc.2004-0535

58. Pi-Sunyer FX. The obesity epidemic: Pathophysiology and consequences of obesity. Obes Res 2002;10(2):97s-104s. https://doi.org/10.1038/oby.2002.202

59. Yang J, Zheng Y, Gou X, et al. Prevalence of comorbidities and its effects in patients infected with SARSCoV-2: A systematic review and meta-analysis. Int J Infect Dis 2020;94:91-95. https://doi.org/10.1016/j. ijid.2020.03.017

60. Poulain M, Doucet M, Major GC, et al. The effect of obesity on chronic respiratory diseases: Pathophysiology and therapeutic strategies. CMAJ 2006;174(9):1293-1299. https://doi.org/10.1503/cmaj.051299

61. Zammit C, Liddicoat H, Moonsie I, Makker H. Obesity and respiratory diseases. Int J Gen Med 2010;3:335-343. https://doi.org/10.2147/IJGM.S11926

62. Mafort TT, Rufino R, Costa CH, Lopes AJ. Obesity: Systemic and pulmonary complications, biochemical abnormalities, and impairment of lung function. Multidiscip Respir Med 2016;11(1):28. https://doi. org/10.1186/s40248-016-0066-

63. Kornblith LZ, Howard B, Kunitake R, et al. Obesity and clotting: Body mass index independently contributes to hypercoagulability after injury. J Trauma Acute Care Surg 2015;78(1):30-38. https://dx.doi. org/10.1097/TA.0000000000000490

64. Poissy J, Goutay J, Caplan M, et al. Pulmonary embolism in COVID-19 patients: Awareness of an increased prevalence. Circulation 2020;142(2):184-186. https://doi.org/10.1161/circulationaha.120.047430

65. Beenen LFM, Scheres LJJ, Stoker J, Middeldorp S. Prognostic characteristics and body mass index in patients with pulmonary embolism: Does size matter? ERJ Open Res 2020;6(1):00163-02019. https://doi org/10.1183/23120541.00163-2019

66. Rhee CM, Ahmadi SF, Kalantar-Zadeh K. The dual roles of obesity in chronic kidney disease: A review of the current literature. Curr Opin Nephrol Hypertens 2016;25(3):208-216. https://doi.org/10.1097/ MNH.0000000000000212

67. Oyelade T, Alqahtani J, Canciani G. Prognosis of COVID-19 in patients with liver and kidney diseases: An early systematic review and meta-analysis. Trop Med Infect Dis 2020;5(2):80. https://doi.org/10.3390/ tropicalmed 5020080

68. Statistics South Africa. South Africa demographic and health survey (SADHS). Pretoria: SSA, 2016. https://dhsprogram.com/pubs/pdf/FR337/FR337.pdf (accessed 3 August 2020).

69. Human Sciences Research Council. South African national health and nutrition examination survey (NHANES-1). Cape Town: HSRC, 2013, http://repositoryhsrc.ac.za/handle/20.500.11910/2864 (accessed 3 August 2020).

70. South African Medical Research Council. Chronic diseases of lifestyle in South Africa. Cape Town: SAMRC, 2005. https://www.samrc.ac.za/reports/chronic-diseases-lifestyle-south-africa-1995-2005. (accessed 5 August 2020).

71. National Department of Health (NDoH). Strategy for the prevention and control of obesity in South Africa 2015 - 2020. Pretoria, NDoH, 2016. https://health-e.org.za/2015/12/28/strategy-the-preventionand-control-of-obesity-in-south-africa-2015-2020/ (accessed 5 August 2020).

72. Statistics South Africa (StatsSA). Work \& labour force. Pretoria: StatsSA, 2020. http://www.statssa.gov. za/?page_id=737\&id=1 (accessed 13 August 2020).

73. Statistics South Africa. Poverty and inequality. Pretoria: SSA, 2015. http://www.statssa.gov.za/?cat=31 (accessed 13 August 2020).

74. Statistics South Africa (StatsSA). National poverty lines. Pretoria: StatsSA, 2019. http://www.statssa.gov. za/publications/P03101/P031012020.pdf (accessed 13 August 2020).

75. National Department of Health (NDoH). Coronavirus South African resource portal. Pretoria: $\mathrm{NDoH}$ 2020. https://sacoronavirus.co.za/?gclid=CjwKCAjwh7H7BRBBEiwAPXjadr2winJXUKP7HYK6qBaiqY ldejd44JSZjxpilogjlQJr3io04DL9PBoCgnYQAvD_BwE (accessed 14 September 2020).

76. Kosaraju R, Guesdon W, Crouch MJ, et al. B cell activity is impaired in human and mouse obesity and is responsive to an essential fatty acid upon murine influenza infection. J Immunol 2017;198(12):47384752. https://doi.org/10.4049/jimmunol.1601031

77. Albashir AAD. The potential impacts of obesity on COVID-19. Clin Med 2020;20(4):e109-el13. https:// doi.org/10.7861/clinmed.2020-0239

78. Luzi L, Radaelli MG. Influenza and obesity: Its odd relationship and the lessons for COVID-19 pandemic. Acta Diabetol 2020;57(6):759-764. https://doi.org/10.1007/s00592-020-01522-8

79. Honce R, Karlsson EA, Wohlgemuth N, et al. Obesity-related microenvironment promotes emergence of virulent influenza virus strains. mBio 2020;11(2):e03341-03319. https:/doi.org/10.1128/mBio.03341-19

80. Honce R, Schultz-Cherry S. Impact of obesity on influenza A virus pathogenesis, immune response, and evolution. Front Immunol 2019;10:1071. https://doi.org/10.3389/fimmu.2019.01071 